\title{
EKSPLORASI DAN UJI VIRULENSI BAKTERI Bacillus sp. ENDOFIT JAGUNG TERHADAP PENYAKIT BUSUK PELEPAH JAGUNG
}

\author{
Arum Saputri ${ }^{1}$, Loekas Soesanto ${ }^{1 *}$, Endang Mugiastuti $^{1}$, Abu Umayah ${ }^{2}$, Agus Sarjito $^{1}$ \\ ${ }^{1}$ Fakultas Pertanian, Universitas Jenderal Soedirman \\ ${ }^{2}$ Fakultas Pertanian, Universitas Sriwijaya \\ * Corresponding Author: lukassusanto26@gmail.com
}

\begin{abstract}
[EXPLORATION AND VIRULENCE TEST OF MAIZE ENDOPHYTE Bacillus sp. AGAINST MAIZE SHEATH BLIGHT]. Capability of endophytic bacterial, effectivity, and its effect on Rhizoctonia solani. and on maize seedlings growth were investigated from April 2018 to January 2019. Exploration of endophytes bacteria in maize was taken from Banyumas Regency (Sumbang, Kembaran, Baturraden) and Purbalingga Regency (Padamara, Bojongsari, Pratin). Taking plant samples using Purposive Random Sampling and Diagonal Sampling methods. Completely randomized design was used in in vitro test with 16 treatments repeated twice. Completely randomized block design was used in in planta experiment with 5 treatments repeated 5 times. The treatment consisted of control, fungiside (mankozeb), and 2 isolates of endophytes bacteria performing the best in vitro result. Variables observed included characteristics of endophytic bacteria and pathogenic fungi, inhibition diameter, incubation period, disease intensity, incidence of disease, AUDPC, plant height, leaf number, root length, plant fresh weight, canopy fresh weight, and root fresh weight. Resultshowed that the exploration obtained 15 endophytic Bacillus sp. isolates. The PD A.4 and BK A.1 isolates werw able to inhibit the growth of pathogenic fungi in-vitro by 56.93 and $51.5 \%$, respectively. The soaking treatment using BK A1 was able to reduce disease intensity by $59.377 \%$, and AUDPC value $34.19 \%$. Endophytic bacteria influence plant height, plant fresh weight, canopy fresh weight, and fresh weight of roots respectively as $89.17 \mathrm{~cm}, 126.06 \mathrm{~g}, 106.67 \mathrm{~g}$ and $19.4 \mathrm{~g}$.
\end{abstract}

Keyword: Bacillus sp., endophytic bacteria, maize, Rhizoctonia solani

\begin{abstract}
ABSTRAK
Penelitian ini bertujuan untuk mengetahui kemampuan, keefektifan dan pengaruh bakteri antagonis Bacillus sp. endofit tanaman jagung terhadap patogen Rhizoctonia solani. dan terhadap pertumbuhan tanaman jagung. Penelitian dilaksanakan dari April 2018 sampai Januari 2019. Eksplorasi dilakukan di Kabupaten Banyumas (Sumbang, Kembaran, Baturraden) dan di Kabupaten Purbalingga (Padamara, Bojongsari, Pratin). Pengambilan sampel tanaman menggunakan metode Purposive Random Sampling dan Diagonal Sampling. Uji virulensi menggunakan Rancangan Acak Kelompok dengan 5 perlakuan dan diulang 5 kali. Perlakuan terdiri atas kontrol, fungisida (mankoseb), dan 2 isolat bakteri endofit dengan aplikasi perendaman benih. Variabel yang diamati meliputi karakteristik bakteri endofit dan jamur patogen, diameter penghambatan, masa inkubasi, tinggi tanaman, jumlah daun, panjang akar, bobot segar tanaman, bobot segar tajuk, bobot segar akar, intensitas penyakit, kejadian penyakit dan AUDPC. Hasil eksplorasi diperoleh 15 isolat bakteri Bacillus sp. endofit jagung. Bakteri endofit PD A.4 dan BK A.1 mampu menghambat pertumbuhan jamur $R$. solani in-vitro masing masing sebesar $56,93 \%$ dan $51,5 \%$. Perendaman menggunakan bakteri antagonis endofit BK A1 mampu menekan intensitas penyakit sebesar 59,377\%, dan nilai AUDPC 34,19\%. Bakteri endofit berpengaruh terhadap tinggi tanaman, bobot segar tanaman, bobot segar tajuk, dan bobot segar akar secara berturut $89,17 \mathrm{~cm}, 126,06 \mathrm{~g}, 106,67 \mathrm{~g}$ dan $19,4 \mathrm{~g}$.
\end{abstract}

Kata kunci: Bacillus sp. endofit, R. solani, jagung 


\section{PENDAHULUAN}

Jagung merupakan komoditas pangan kedua setelah padi, yang mempunyai peranan strategis dalam pembangunan pertanian dan perekonomian di Indonesia. Selain sebagai bahan makanan pokok, jagung juga digunakan sebagai bahan olahan minyak goreng, tepung maizena, etanol, asam organik, dan industri pakan ternak (Bantacut et al., 2015). Kebutuhan jagung nasional belum sepenuhnya dipenuhi dari produksi jagung nasional. Produktivitas komoditas jagung pada tahun 2015 mencapai 5,918 ton/ha (BPS, 2016). Hal tersebut dikarenakan pola panen jagung mencapai puncaknya hanya pada Bulan Februari, Maret dan April, sedangkan pada bulan lainnya cenderung konstan (Kementerian Pertanian, 2016).

Masa pertumbuhan tanaman jagung tidak lepas dari gangguan organisme pengganggu, termasuk penyakit. Penyakit merupakan faktor pembatas produksi pada tanaman jagung, salah satu penyakit penting pada tanaman jagung adalah penyakit hawar pelepah daun yang disebabkan oleh jamur Rhizoctonia solani Kuhn. (Alexopoulos et al., 1996).

Jamur $R$. solani Kuhn. merupakan jamur patogen tular-tanah yang menghasilkan struktur tahan dan yang lambat menunjukkan gejala. Penyakit busuk pelepah dapat menurunkan bobot tongkol sebesar $17,2 \%$ dan menurunkan bobot biji sebesar 23\% (Soenartiningsih et al., 2006).

Usaha yang telah dilakukan dalam pengendalian patogen ini di antaranya penggunaan varietas tahan (Király et al., 2007; Andersen et al., 2018), pensterilan medium tanam atau solarisasi tanah (Lee et al., 2016), pembenaman bahan organik (Noble, 2011; Lahre et al., 2012), dan penggunaan fungisida (Rozy et al., 2004). Cara tersebut belum memperoleh hasil optimum, sedangkan penggunaan fungisida dapat menimbulkan dampak negatif (Brittain et al., 2011; Keswani et al., 2019), sehingga diperlukan alternatif pengendalian lain yang ramah lingkungan dengan memanfaatkan agensia hayati baik endofit maupun ektofit (Lahre et al., 2012; Bruisson et al., 2019).

Salah satu agensia hayati yang digunakan adalah bakteri Bacillus sp. endofit tanaman jagung. Bakteri endofit adalah bakteri yang terdapat dalam jaringan tanaman, dan dapat diisolasi dan diekstraksi pada medium tumbuh (Hardoim et al., 2015). Bakteri endofit dapat hidup di dalam jaringan akar, batang, daun, dan buah tanaman, dan umumnya mengkoloni bagian antar sel dari jaringan tanaman inang, sistem pembuluh, serta dapat ditranslokasikan secara sistemik ke seluruh bagian tanaman (Simarmata et al., 2007). Keunggulan endofit selain mengatasi pathogen biotik dan abiotik dengan mengubah ketahanan tanaman, juga mendukung pertumbuhan tanaman (Pappas et al., 2018). Bacillus sp. dipilih karena lebih tersebar luas di alam dibandingkan genus lainnya (Sorokulova, 2013). Penelitian ini bertujuan untuk mengetahui kemampuan, keefektifan dan pengaruh bakteri antagonis Bacillus sp. endofit tanaman jagung terhadap patogen $R$. solani. dan terhadap pertumbuhan tanaman jagung.

\section{METODE PENELITIAN}

Penelitian ini dilaksanakan pada bulan April 2018 sampai dengan Januari 2019 dan berlokasi di Laboratorium Perlindungan Tanaman, Fakultas Pertanian, Universitas Jenderal Soedirman dan di Rumah Kaca, Fakultas Pertanian Universitas Jenderal Soedirman.

\section{Eksplorasi patogen dan bakteri antagonis}

Jamur patogen yang digunakan berasal dari eksplorasi di lahan pertanaman jagung di Kelurahan Arcawinangun dengan mengambil sampel tanaman sakit yang memiliki gejala busuk pelepah, dengan ditandai adanya sklerotium pada bagian tanaman. Bakteri endofit dieksplorasi dari Kabupaten Banyumas (Sumbang, Kembaran, Baturraden) dan Kabupaten Purbalingga (Padamara, Bojongsari, Pratin), yang masing-masing mewakili dataran tinggi dan rendah. Pengambilan sampel menggunakan metode Purposive Random Sampling (Taherdoost, 2016). Sampel tanaman jagung diambil secara diagonal dari lahan jagung hibrida. Selanjutnya batang dan akar tanaman jagung dipisah dan diambil sebagai bahan isolasi. Hal ini karena bakteri Bacillus sp. endofit umumnya banyak ditemukan di bagian itu. Bagian tanaman kemudian dimasukkan kantung kertas, diberi label, dan dibawa ke laboratiruium untuk proses selanjutnya (Zhao et al., 2015).

\section{Pengkarakteran bakteri endofit}

Bakteri endofit Bacillus sp. diisolasi dari dalam tanaman jagung (endofit), Bakteri endofit hasil eksplorasi dikarakterisasi morfologinya berdasarkan bentuk koloni, warna koloni, bentuk permukaan, dan bentuk sel (Sousa et al., 2013), pewarnaan gram (Beveridge, 2001), katalase (Whittenbury, 1964), dan endospora (Oktari et al., 2017).

\section{Pengkarakteran jamur patogen}

Jamur patogen hasil eksplorasi dikarakterisasi morfologinya berdasarkan warna koloni, bentuk permukaan, hifa, bentuk sklerotium, dan warna sklerotium. Identifikasi menggunakan buku kunci identifikasi Domsch et al. (1980) dan Watanabe (2002). Selanjutnya, jamur patogen yang ditemukan dilakukan uji Postulat Koch (Byrd \& Segre, 2016).

\section{Pemurnian bakteri endofit dan jamur patogen}

Bakteri endofit Bacillus sp. yang ditemukan kemudian dimurnikan dalam medium NA dan diinkubasi 
pada suhu kamar selama 48 jam (Hasanain, 2017). Jamur $R$. solani dimurnikan dalam PDA dan diinkubasi selama 7 hari pada suhu kamar (Sharma et al., 2013).

\section{Uji in-vitro}

Bakteri hasil eksplorasi diuji daya hambatnya terhadap patogen jamur $R$. solani. Perlakuan yang digunakan yaitu $\mathrm{B}_{0}=$ Kontrol, $\mathrm{BK} \mathrm{A}_{1}=$ Bacillus sp. Banyumas Kembaran Akar 1, BK $\mathrm{A}_{2}=$ Bacillus sp. Banyumas Kembaran Akar 2, BK B 3

$=$ Bacillus sp. Banyumas Kembaran Batang 3, BS $\mathrm{A}_{1}=$ Bacillus sp. Banyumas Sumbang Akar 1, BS $\mathrm{A}_{3}=$ Bacillus sp. Banyumas Sumbang Akar 3, BS $\mathrm{B}_{1}=$ Bacillus sp. Banyumas Sumbang Batang 1, BB $\mathrm{A}_{3}=$ Bacillus sp. Banyumas Baturaden Akar 3, BB $\mathrm{B}_{4}=$ Bacillus sp. Banyumas Baturaden Batang 4, PP $\mathrm{A}_{4}=$ Bacillus sp. Purbalingga Padamara Akar 4, PD $\mathrm{B}_{2}=$ Bacillus sp. Purbalingga Padamara Batang 2, $\mathrm{PD} \mathrm{B}_{4}=$ Bacillus sp. Purbalingga Padamara Batang 4, $\mathrm{PB} \mathrm{B}_{1}=$ Bacillus sp. Purbalingga Bojongsari Batang 1, PB $\mathrm{B}_{3}=$ Bacillus sp. Purbalingga Bojongsari Batang 3 . PP $\mathrm{A}_{3}=$ Bacillus sp. Purbalingga Pratin Akar 3, dan PP $\mathrm{A}_{5}=$ Bacillus sp. Purbalingga Pratin Akar 5. Uji in -vitro dilakukan menggunakan Rancangan Acak Lengkap dengan 16 perlakuan dan diulang 2 kali, kemudian dilakukan uji beda rata-rata menggunakan BNT pada taraf $5 \%$.

\section{Persiapan bibit}

Benih jagung varietas Arumba direndam dalam air steril (sebagai kontrol) atau dalam biakan bakteri endofit dengan kepadatan populasi $10^{8} \mathrm{upk} / \mathrm{mL}$ selama 12 jam (Sharma et al., 2013).

\section{Perbanyakan bakteri endofit}

Bakteri dengan daya hambat tertinggi yaitu $\mathrm{PD}$ $\mathrm{A}_{4}$ dan $\mathrm{BK} \mathrm{A}_{1}$ digunakan dalam uji virulensi.

\section{Uji virulensi}

Perlakuan yang dilakukan adalah $\mathrm{K}=$ Kontrol (air steril). $\mathrm{B}_{1}=$ Fungisida berbahan aktif propineb, $\mathrm{B}_{2}=$ Bacillus sp. Purbalingga Padamara Akar 4, $\mathrm{B}_{3}=$ Bacillus sp. Banyumas Kembaran Akar 1, dan $\mathrm{B}_{4}=$ Campuran Bacillus sp. Padamara Akar 4 dan Kembaran Akar 1. Hasil uji virulensi kemudian dianalisis menggunakan Rancangan Acak Kelompok Lengkap dan uji beda rata-rata yang digunakan adalah BNT pada taraf $5 \%$.

\section{Variabel pengamatan}

Variabel yang diamati yaitu karakteristik bakteri endofit dan jamur patogen, diameter penghambatan, berat kering miselium jamur patogen (de Souza et al., 2011), masa inkubasi, tinggi tanaman, jumlah daun, panjang akar, bobot segar tanaman, bobot segar tajuk, bobot segar akar, intensitas penyakit, kejadian penyakit dan AUDPC. Rumus menghitung persentase penghambatan (Hajiegharai et al., 2008):

$$
\mathrm{P}=\frac{\mathrm{r} 1-\mathrm{r} 2}{\mathrm{r} 1} \times 100 \%
$$

Keterangan: $\mathrm{P}=$ persentase penghambatan, $\mathrm{r} 1=$ jari-jari isolat $R$. solani yang tumbuh berlawanan dengan antagonis, $\mathrm{r} 2=$ jari-jari isolat $R$. solani yang tumbuh ke arah antagonis.

Pengamatan kejadian penyakit dilakukan setiap tujuh hari sekali, dan besarannya dapat dihitung menggunakan rumus (Noordzij et al., 2010):

$$
\mathrm{KP}=\frac{\overline{\mathrm{n}}}{\mathrm{N}} \times 100 \%
$$

Keterangan: $\mathrm{n}$ : jumlah tanaman bergejala, $\mathrm{N}$ : jumlah tanaman total yang diamati.

Perhitungan intensitas penyakit dihitung menggunakan rumus (Asmaliyah et al., 2016):

$$
\mathrm{IP}=\frac{\sum(n x v)}{Z x N} \times 100 \%
$$

Keterangan: IP $=$ intensitas penyakit $(\%), \mathrm{n}=$ jumlah daun bergejala penyakit dengan skala tertentu, $\mathrm{v}=$ nilai hasil pengukuran satuan pengamatan, $\mathrm{Z}=$ nilai numerik tertinggi kategori kerusakan.

Nilai rata-rata intensitas penyakit digunakan sebagai acuan untuk menentukan ketahanan. Nilai kategori keparahan penyakit: $0=$ tidak ada gejala pada pelepah daun, $1=0-20 \%$ pelepah daun bergejala, $2=$ $>20-40 \%$ pelepah daun bergejala, $3=>40-60 \%$ pelepah daun bergejala, dan $4=>60 \%$ pelepah daun bergejala (Mulyati, 2009).

Laju perkembangan penyakit dari waktu ke waktu dihitung dengan formula AUDPC sebagai berikut (Jeger \& Viljanen-Rollinson, 2001): 


$$
\mathrm{AUDPC}=\sum_{i=0}^{n-1}\left(\frac{\mathrm{Yi}+\mathrm{Yi}+1}{2}\right) \cdot\left(\mathrm{t}_{i+1}-t_{i}\right)
$$

Keterangan: AUDPC: Kurva perkembangan penyakit, Y = keparahan penyakit pada waktu $\mathrm{t}, \mathrm{i}=$ jumlah hari setelah tanam, waktu oengamatan ke-i, $\mathrm{n}=$ jumlah total pengukuran.

\section{Analisis data}

Data yang diperoleh dari pengamatan dan pengukuran akan dianalisis dengan uji $\mathrm{F}$, dan apabila hasil analisis menunjukkan adanya keragaman nyata $(\mathrm{F}$ hitung $>\mathrm{F}$ tabel) maka dilanjutkan dengan uji beda rata-rata $\mathrm{BNJ}$ pada taraf nyata $5 \%$ untuk mengetahui isolat yang terbaik.

\section{HASIL DAN PEMBAHASAN}

\section{Isolasi bakteri endofit dan jamur patogen pada tanaman jagung}

Hasil eksplorasi bakteri antagonis endofit tanaman jagung diperoleh 15 isolat, yang memiliki karakter bakteri Bacillus sp. Bentuk koloni bulat, bentuk sel batang, berwarna ungu termasuk dalam kelompok bakteri gram positif. Ciri lain dari bakteri Bacillus sp. yang diperoleh adalah adanya endospora dalam sel (Tabel 1). Hal tersebut sesuai dengan Lu et al. (2018), bahwa Bacillus sp. memiliki ciri-ciri koloni bulat dan bulat kecil, variasi margin halus dan berombak atau bergerigi, berwarna putih kusam, tidak berlendir, gram positif, memiliki endospora, berflagelum, dan sebagian bersifat motil (dapat bergerak).

Pengujian gram menggunakan $\mathrm{KOH} \mathrm{3 \%}$ menunjukkan hasil positif karena bakteri ini tidak lengket, dan untuk katalase menggunakan $\mathrm{H}_{2} \mathrm{O}_{2}$ menunjukkan hasil positif yang ditandai adanya gelembung. Berdasarkan hasil uji pewarnaan spora terlihat bahwa seluruh isolat bakteri yang berbentuk batang terlihat memiliki spora (endospora). Endospora terlihat pada bagian tengah sel bakteri, yang ditandai dengan adanya warna hijau pada bagian tengah sel bakteri. Berdasarkan kunci identifikasi, bakteri yang memiliki ciri-ciri gram positif, berbentuk batang dan memiliki endospora diduga termasuk ke dalam genus Bacillus (Lu et al., 2018).

Hasil karakterisasi jamur patogen diketahui bahwa jamur $R$. solani yang diamati memiliki hifa berwarna putih, kemudian membentuk sklerotium berwarna coklat. Karakterisasi secara mikroskopis menunjukkan jamur memiliki hifa bercabang tegak lurus. Hal ini sesuai dengan hasil penelitian Suryawanshi et al. (2019) bahwa R. solani tumbuh cepat dalam medium PDA dan membentuk tekstur koloni berkapas dan sklerotium berwarna coklat tua sampai hitam.

Hifa $R$. solani yang masih muda memiliki percabangan yang membentuk sudut 45 derajat. Semakin dewasa, percabangannya tegak urus, kaku, dan memiliki ukuran yang sama (uniform). Diameter hifa jamur $R$. solani bergantung pada isolat dan jenis medium yang digunakan. Jamur yang diisolasi menggunakan medium PDA memiliki diameter hifa 4-6 $\mu \mathrm{m}$. Sklerotium dari

Tabel 1. Karakterisasi morfologi bakteri antagonis Bacillus sp.

\begin{tabular}{cccccccc}
\hline Isolat & $\begin{array}{c}\text { Warna } \\
\text { koloni }\end{array}$ & $\begin{array}{c}\text { Bentuk } \\
\text { koloni }\end{array}$ & Bentuk sel & $\begin{array}{c}\text { Warna } \\
\text { Gram }\end{array}$ & $\begin{array}{c}\text { Katalase } \\
\left(\mathrm{H}_{2} \mathrm{O}_{2}\right)\end{array}$ & $\begin{array}{c}\text { Gram } \\
(\mathrm{KOH} \\
3 \%)\end{array}$ & $\begin{array}{c}\text { Endo- } \\
\text { spora }\end{array}$ \\
\hline BK A1 & Putih & Bulat & Batang pendek & Ungu & + & + & + \\
BK A3 & Putih & Bulat & Batang panjang & Ungu & + & + & + \\
BK B3 & Putih & Bulat & Batang panjang & Ungu & + & + & + \\
BS A1 & Putih & Bulat & Batang panjang & Ungu & + & + & + \\
BS A3 & Putih & Bulat & Batang pendek & Ungu & + & + & + \\
BS B1 & Putih & Bulat & Batang pendek & Ungu & + & + & + \\
BB A3 & Putih & Bulat & Batang pendek & Ungu & + & + & + \\
BB B4 & Putih & Bulat & Batang pendek & Ungu & + & + & + \\
PD A4 & Putih & Bulat & Batang panjang & Ungu & + & + & + \\
PD B2 & Putih & Bulat & Batang pendek & Ungu & + & + & + \\
PD B4 & Putih & Bulat & Batang panjang & Ungu & + & + & + \\
PB B1 & Putih & Bulat & Batang pendek & Ungu & + & + & + \\
PB B3 & Putih & Bulat & Batang panjang & Ungu & + & + & + \\
PP A3 & Putih & Bulat & Batang pendek & Ungu & + & + & + \\
PP A5 & Putih & Bulat & Batang panjang & Ungu & + & + & + \\
\hline
\end{tabular}

Keterangan: $\mathrm{BK}=$ Banyumas Kembaran, $\mathrm{BS}=$ Banyumas Sumbang, $\mathrm{BB}=$ Banyumas Baturraden, $\mathrm{PD}=$ Purbalingga Padamara, $\mathrm{PB}=$ Purbalingga Bojongsari, $\mathrm{PP}=$ Purbalingga Pratin, $\mathrm{A}=\mathrm{Akar}$ dan $\mathrm{B}=\mathrm{Batang}$. 
jamur $R$. solani terbentuk dari hifa yang mengalami agregasi menjadi massa yang kompak. Sklerotium pada awal pertumbuhan berwarna putih dan setelah dewasa berubah menjadi coklat (Gopireddy et al., 2017).

Uji in-vitro bakteri endofit Bacillus sp. terhadap pertumbuhan jamur $R$. solani

Hasil uji antagonis dual culture bakteri antagonis Bacillus sp. terhadap jamur patogen $R$. solani menunjukkan pengaruh sangat nyata dalam menghambat pertumbuhan jamur patogen $R$. solani apabila dibandingkan dengan kontrol (Tabel 2). Bakteri endofit yang memiliki persentase penghambatan paling besar adalah isolat bakteri $\mathrm{PD} \mathrm{A}_{4}$ dengan persentase penghambatan sebesar $56,93 \%$, sedangkan isolat yang menunjukkan adanya tingkat penghambatan terkecil adalah isolat PB B1 yakni sebesar 37,29\%.

Penghambatan dapat terjadi diduga akibat adanya mekanisme penghambatan yang dihasilkan oleh bakteri Bacillus sp., yang dalam hal ini adalah persaingan nutrisi dan adanya antibiotika yang dihasilkan oleh bakteri tersebut. Penghambatan jamur $R$. solani oleh bakteri Bacillus sp. dapat terjadi dikarenakan Bacillus sp. mampu menghasilkan siderofor, 1,3-glukanase, sianida, kitinase, antibiotika dan dapat melarutkan fosfat yang diketahui mampu menekan pertumbuhan dari mikroba yang merugikan (Husen, 2003; Frederiksen et al., 2013).

Bobot kering miselium jamur patogen menunjukkan hasil terkecil pada isolat PD A.4 jika dibandingkan dengan isolat lain dan kontrol (Tabel 2). Hal ini selaras dengan kemampuan menghambat dari isolat tersebut. Penghambatan pertumbuhan jamur yang rendah akan menghasilkan biomassa jamur yang rendah pula. Menurut Souza et al. (2012), biomasa jamur dipengaruhi oleh komponen perkembangan jamur; jika jamur dapat berkembang dengan baik, maka akan menghasilkan biomassa yang besar.

\section{Pengaruh bakteri endofit Bacillus sp. terhadap komponen patosistem dan komponen pertumbuhan tanaman}

Perlakuan bakteri Bacillus sp. kombinasi isolat $\mathrm{PD}_{4}$ dan $\mathrm{BK} \mathrm{A}_{1}$ mampu menunda masa inkubasi jamur $R$. solani selama 14,2 hari setelah inokulasi (Hsi) atau sebesar $69,24 \%$ dibandingkan dengan kontrol (Tabel 3). Hal tersebut dapat terjadi dikarenakan bakteri endofit mampu menghasilkan antibiotika. Menurut
Kuta et al. (2009), beberapa spesies Bacillus berpotensi menghasilkan antibiotika berkualitas tinggi, yang dapat digunakan untuk mengendalikan pertumbuhan mikroba patogen tanaman. Spesies Bacillus paling populer untuk memproduksi senyawa antibiotika peptida, seperti polimiksin, colistin, dan sirkulin (Katz \& Demain, 1997).

Perlakuan terbaik dalam menekan kejadian penyakit terdapat pada perlakuan B1 yakni sebesar 44,446\% atau sebesar 52,94\% (Tabel 3). Hal yang dapat memengaruhi terjadinya penyakit busuk pelepah ini yakni ketinggian tempat, iklim, dan varietas. Jamur $R$. solani dapat berkembang dengan baik pada kelembapan yang tiggi $(>80 \%)$ dan suhu 15-35 ${ }^{\circ} \mathrm{C}$ (Orozco-Avitia et al., 2013).

Tabel 2. Daya hambat bakteri antagonis terhadap jamur patogen $R$. solani dan bobot kering miselium $R$. solani pengamatan hari ke-4 pada pengujian in vitro

\begin{tabular}{|c|c|c|}
\hline Perlakuan & $\begin{array}{c}\text { Persentase } \\
\text { penghambatan }(\%)\end{array}$ & $\begin{array}{l}\text { Bobot kering } \\
\text { miselium }(\mathrm{g})\end{array}$ \\
\hline Kontrol & $f$ & 0,0956 \\
\hline BK A1 & $51,52 a b c$ & 0,003 \\
\hline BK A3 & $55,39 \mathrm{ab}$ & 0,0019 \\
\hline BK B3 & 40,36 cde & 0,0305 \\
\hline BS A1 & 48,73 abcde & 0,0156 \\
\hline $\mathrm{BS} \mathrm{A} 3$ & $37,42 \mathrm{de}$ & 0,0392 \\
\hline BS B1 & $49,74 \mathrm{abcd}$ & 0,0118 \\
\hline $\mathrm{BB} A 3$ & 40,42 cde & 0,0296 \\
\hline BB B4 & 44,44 bcde & 0,0257 \\
\hline PD A4 & 56,93 a & 0,0017 \\
\hline PD B2 & $50,80 \mathrm{abc}$ & 0,007 \\
\hline PD B4 & 39,44 cde & 0,0358 \\
\hline PB B1 & $37,29 \mathrm{e}$ & 0,0466 \\
\hline PB B3 & 44,90 abcde & 0,0215 \\
\hline PP A3 & 46,65 abcde & 0,0193 \\
\hline PPA5 & $50,66 a b c$ & 0,0093 \\
\hline \multicolumn{3}{|c|}{$\begin{array}{l}\text { Keterangan : angka-angka yang diikuti oleh huruf yang } \\
\text { sama pada kolom yang sama berbeda tidak nyata pada } \\
\text { BNT } 5 \% . B K=B a n y u m a s \text { Kembaran, } B S=B a n y u m a s \\
\text { Sumbang, BB= Banyumas Baturraden, } P D=P u r b a l i n g g a \\
\text { Padamara, } P B=\text { Purbalingga Bojongsari, PP= } \\
\text { Purbalingga Pratin, A= Akar dan B= Batang. }\end{array}$} \\
\hline
\end{tabular}


Tabel 3. Komponen patosistem bakteri Bacillus sp. endofit terhadap penyakit busuk pelepah tanaman jagung dan terhadap komponen pertumbuhan tanaman jagung

\begin{tabular}{|c|c|c|c|c|c|c|c|c|c|c|}
\hline Perlakuan & $\begin{array}{c}\text { Masa } \\
\text { Inkubasi } \\
\text { (Hsi) }\end{array}$ & $\begin{array}{c}\text { Kejadian } \\
\text { Penyakit } \\
(\%) \\
\end{array}$ & $\begin{array}{c}\text { Intensits } \\
\text { Penyakit } \\
(\%) \\
\end{array}$ & AUDPC & TT $(\mathrm{cm})$ & JD (helai) & $\mathrm{PA}(\mathrm{cm})$ & BST (g) & $\mathrm{BSTa}(\mathrm{g})$ & BSA (g) \\
\hline Kontrol & $8,398 \mathrm{a}$ & $94,444 \mathrm{~b}$ & $53,334 \mathrm{~b}$ & 3616,69 & $71,776 \mathrm{~b}$ & $4,667 \mathrm{a}$ & $80,16 \mathrm{a}$ & 110 & $91,9 \quad b$ & 18,1 a \\
\hline $\begin{array}{l}\text { Fungisida } \\
\text { (propineb) }\end{array}$ & $7,665 \mathrm{a}$ & $51,111 \mathrm{ab}$ & $26,664 \mathrm{a}$ & 1936,69 & 94,66 a & $4,533 \mathrm{a}$ & $67,33 \mathrm{a}$ & 120,99 a & 90,07 a & $18,47 \mathrm{a}$ \\
\hline PD A4 & $6,867 \mathrm{a}$ & $44,446 \mathrm{a}$ & $23,332 \mathrm{a}$ & 1679,89 & $89,073 \mathrm{a}$ & $4,533 \mathrm{a}$ & $75,65 \mathrm{a}$ & 126,06 a & $106,67 \mathrm{a}$ & 19,4 a \\
\hline BK A1 & $6,933 \mathrm{a}$ & $62,222 \mathrm{ab}$ & $21,666 \mathrm{a}$ & 2380,11 & $\begin{array}{l}81,17 \\
a b\end{array}$ & $4,067 \mathrm{a}$ & $65,81 \mathrm{a}$ & 113,76 a & $97,1 \quad$ a & $16,66 \mathrm{a}$ \\
\hline $\begin{array}{l}\mathrm{PD} \mathrm{A4}+ \\
\text { BK A1 }\end{array}$ & 14,2 a & $57,777 \mathrm{ab}$ & $30 \quad \mathrm{ab}$ & 2169,89 & $\begin{array}{l}86,806 \\
\mathrm{ab}\end{array}$ & $4,2 \quad a$ & 76,0 a & $109,266 \mathrm{a}$ & $94,53 \mathrm{a}$ & $14,73 \mathrm{a}$ \\
\hline
\end{tabular}

Keterangan: Angka-angka yang diikuti huruf yang sama pada kolom yang sama menunjukkan perbedaan tidak nyata pada BNT 5\%. AUDPC - area under the disease progress curve, TT = tinggi tanaman, JD = jumlah daun, $\mathrm{PA}=$ panjang akar, BST = bobot segar tanam, BSTa = bobot segar tajuk, dan BSA = bobot segar akar

Penekanan intensitas penyakit secara berurutan sebesar 21,666, 23,332 dan 26,664\% atau terjadi penekanan sebesar 59,377, 56,253 dan 50,005\% apabila dibandingkan dengan kontrol. Hal tersebut dapat terjadi karena adanya kemampuan bakteri dalam memproduksi siderofor. Hal ini karena siderofor mampu mengikat besi $\left(\mathrm{Fe}^{3+}\right)$ menjadi ikatan siderofor-besi yang menjadi tersedia bagi tanaman dan tidak tersedia bagi patogen. Hal ini sesuai dengan pendapat Yusra et al. (2014), bahwa B. subtilis CAS15 menghasilkan siderofor katekolik 2,3-dihydroxybenzoate-glycinetreonic trimeric ester bacillibactin, dan bahwa produktivitas siderophore dihambat oleh zat besi. Selain sebagai pengangkut besi, siderofor juga berperan dalam pertumbuhan, perkecambahan, dan beberapa sebagai antibiotika yang berpotensi (Grobelak \& Hiller, 2017).

Hasil analisis AUDPC pada perlakuan Bacillus sp. mampu menurunkan nilai AUDPC kontrol. Nilai AUDPC terendah terdapat pada perlakuan BK $\mathrm{A}_{1}$ sebesar 1679,89 atau sebesar 53,55\% (Tabel 3). Angka AUDPC yang semakin rendah menunjukkan perlakuan semakin efektif dalam mengendalikan patogen, dan sebaliknya, semakin besar angka AUDPC maka perlakuan semakin tidak berpengaruh terhadap infeksi patogen (Nuryani et al., 2011). Tanaman yang tergolong mengalami penyakit dalam penelitian ini adalah tanaman yang terpapar jatuh dan menimbulkan gejala. Menurut Gilbert \& Parker (2010), pada tanaman kontrol rata-rata tanaman mengalami insiden penyakit tertinggi. Kejadian penyakit tertinggi dalam kontrol disebabkan oleh aktivitas patogen yang lebih cepat masuk dan kemudian menginfeksi jaringan tanaman dan tidak adanya mekanisme ketahanan tanaman terhadap infeksi patogen.

Perlakuan terbaik terhadap tinggi tanaman jagung ada pada perlakuan fungisida yaitu $94,66 \mathrm{~cm}$, namun untuk perlakuan dengan bakteri antagonis ternyata memiliki nilai yang tidak jauh selisihnya yaitu $89,073 \mathrm{~cm}$ pada perlakuan $\mathrm{B}_{1}$ (Tabel 3). Pengaruh terhadap bobot segar tajuk tanaman juga menunjukkan adanya perbedaan nyata, dengan perlakuan terbaik pada perlakuan $\mathrm{B}_{1}$ dengan nilai sebesar $126,06 \mathrm{~g}$.

Perlakuan bakteri endofit menunjukkan pengaruh yang nyata terhadap komponen tinggi tanaman dan bobot segar tajuk tanaman. Hal ini dikarenakan kemampuan dari bakteri Bacillus sp. endofit untuk menghasilkan hormon pertumbuhan. Bakteri tersebut mampu menghasilkan hormon IAA (Indole Acetic Acid) dan hormon pertumbuhan yang lain (Junior et al., 2015; Wagi \& Ahmed, 2019).

Bakteri Bacillus sp. yang diberikan pada pertanaman jagung dapat bersifat sebagai PGPR yang dapat menguntungkan bagi tanaman. PGPR sangat berperan di dalam pertumbuhan tanaman sehat dan keberlanjutan pertanian (Gupta et al., 2015). Bakteri ini diketahui mampu mengendalikan beberapa patogen tular-tanah dan mampu memacu pertumbuhan tanaman serta menghasilkan antimikroba yang dapat menekan pertumbuhan berbagai patogen tanaman (Shafi et al., 2017; Fira et al., 2018). 


\section{KESIMPULAN}

Hasil eksplorasi diperoleh 15 isolat bakteri endofit Bacillus sp. Isolat terbaik adalah $\mathrm{PD} \mathrm{A}_{4}$ dan $\mathrm{BK} \mathrm{A}_{1}$ yang berturut-turut memiliki nilai penghambatan sebesar 56,93 dan $51,52 \%$ dengan bobot kering miselium seberat $0,0017 \mathrm{~g}$ dan $0,003 \mathrm{~g}$. Perlakuan kombinasi $\mathrm{PD} \mathrm{A} 4+\mathrm{BK} \mathrm{A}_{1}$ mampu menunda masa inkubasi selama 14,2 hari atau sebesar 69,24\% dibandingkan dengan kontrol. Perlakuan bakteri PD $\mathrm{A}_{4}$ mampu menekan kejadian penyakit sebesar $44,446 \%$ atau sebesar $52,94 \%$, penekanan intensitas penyakit sebesar 56,253\% dan nilai AUDPC sebesar 53,55\%. Perlakuan dengan bakteri endofit PD $\mathrm{A}_{4}$ dapat meningkatkan tinggi tanaman, bobot segar tanaman, bobot segar tajuk, dan bobot segar akar berturut-turut 19,41, $16,07,12,74$, dan $7,18 \%$.

\section{DAFTAR PUSTAKA}

Alexopoulos, C.J., Mims, C.W. \& Blackwell, M. (1996). Introductory Mycologi. John Wiley \& Sons., Singapore.

Andersen, E.J., Ali, S., Byamukama, E., Yen, Y. \& Nepalm M.P.. (2018). Disease resistance mechanisms in plants. Genes (Basel). 9(7): 339. DOI: https://10.3390/genes9070339.

Asmaliyah, A., Lukman, H. \& Mindawati, N. (2016). Pengaruh teknik persiapan lahan terhadap serangan hama penyakit pada tegakan bambang lanang. Jurnal Penelitian Hutan Tanaman, 13(2), 139-155.

Bantacut, T., Firdaus, Y.R. \& Akbar, M.T. (2015). Pengembangan jagung untuk ketahanan pangan, industri dan ekonomi. Jurnal Pangan, 24(2), 135-148.

Beveridge, T.J. (2001). Use of the gram stain in microbiology. Biotech Histochem, 76(3), 111118.

BPS. (2016). Luas panen, produksi, dan produktivitas jagung dan kedelai menurut kabupaten/ kota di Provinsi Jawa Tengah, 2015. Badan Pusat Statistik Jawa Tengah. (On-line), https:// jateng.bps.go.id/statictable/2016/ 08/22/1312/ luas-panen-produksi-dan-produktivitasjagung-dan-kedelai-menurut-kabupaten-kotadi-provinsi-jawa-tengah-2015.html. Diakses 14 Agustus 2018.

Brittain, C.A., Vighi, M., Bommarco, R., Settele, J. \& Potts, S.G. (2011). Impacts of a pesticide on pollinator species richness at different spatial scales. Basic and Applied Ecology 11(2), 106115. DOI: https://10.1016/j.baae.2009.11.007.

Bruisson, S., Zufferey, M., Haridon, F.L., Trutmann, E., Anand, A., Dutartre, A., De Vrieze, M. \& Weisskopf, L. (2019). Endophytes and epiphytes from the grapevine leaf microbiome as potential biocontrol agents against phytopatho-gens. Front. Microbiol., 29 November 2019. DOI:https:// doi.org/10.3389/fmicb.2019. 02726.

Byrd, A.L. \& Segre, J.A. (2016). Adapting Koch's postulates. Science, 351(6270), 224-226. DOI: https://10.1126/science.aad6753.

de Souza, M.M., Prietto, L., Ribeiro, A.C., de Souza, T.D. \& Badiale-Furlong, E. (2011). Assessment of the antifungal activity of Spirulina platensis phenolic extract against Aspergillus flavus. Ciência e Agrotecnologia, 35(6). DOI: https://10.1590/S1413-70542011000600003.

Domsch, K.H., Gams, W. \& Anderson, T.H. (1980). Compedium of Soil Fungi. Academic Press. New York.

Fira, D., Dimkić, I., Berić, T., Lozo, J. \& Stanković, S. (2018). Biological control of plant pathogens by Bacillus species. Journal of Biotechnology 285, 44-55. DOI: 10.1016/j.jbiotec.2018.07.044.

Frederiksen, R.F., Paspaliari, D.K., Larsen, T., Storgaard, B.G., Larsen, M.H., Ingmer, H., Palcic, M.M., \& Leisner, J.J. (2013). Bacterial chitinases and chitin-binding proteins as virulence factors. Microbiology, 159, 833-847. DOI: https://10.1099/mic.0.051839-0.

Gilbert, G.S. \& Parker, I.M. (2010). Rapid evolution in a plant-pathogen interaction and the consequences for introduced host species. Evol Appl. 3(2): 144-156. DOI: 10.1111/ j.1752-4571.2009.00107.x.

Gopireddy, B.M., Devi, G.U., Kumar, K.V., Babu, T.R., \& Naidu, T.C.M. (2017). Cultural and morphological characterization of Rhizoctonia solani f. sp. sasakii isolates collected from different districts of Andhra Pradesh. International Journal of Current Microbiology and Applied Sciences, 6(11), 3457-3469. DOI: https://10. 20546/ijcmas.2017.611.407.

Grobelak, A. \& Hiller, J. (2017). Bacterial siderophores promote plant growth: Screening of catechol and hydroxamate siderophores. International Journal of Phytoremediation 19(9), 825-833. DOI: http://10.1080/15226514.2017.1290581.

Gupta, G., Parihar, S.S., Ahirwar, N.K., Snehi, S.K. \& Singh, V. (2015). Plant Growth Promoting Rhizobacteria (PGPR): current and future prospects for development of sustainable agriculture. Journal of Microbial \& Biochemical Technology, 7(2),096-102.DOI:https://10.4172/1948-5948. 1000188.

Hajiegharai, B., Torabi-giglou, M., Mohammadi, M.R. \& Davari, M. (2008). Biological potential of some Iranian Trichoderma isolates in the control of soil born plant pathogenic fungi. African Journal of Biotechnology, 7(8), 967-972.

Hardoim, P.R., van Overbeek, L.S., Berg, G., Pirttilä, A.M., Compant, S., Campisano, A., Döring, M. 
\& Sessitsch, A (2015). The hidden world within plants: ecological and evolutionary considerations for defining functioning of microbial endophytes. Microbiol. Mol. Biol. Rev., 79, 293-320. DOI: https://10.1128/MMBR.00050-14.

Hasanain, A.M. (2017). Development of a cheap media for Bacillus thuringiensis growth. Int J Biotech \& Bioeng. 3(6), 221-229. DOI: https://10.25141/ 2475-3432-2017-6.0216.

Husen, E. (2003). Screening of soil bacteria for plant growth promotion activities in vitro. Indonesian Journal of Agricultural Science. 4(1), 27-31.

Jeger, M.J. \& Viljanen-Rollinson, S.L.H. (2001). The use of the area under disease-progress curve (audpc) to asses quantitive disease resistance in crop cultivars. Theoretical Applied Genetics 102(1), 32-40. DOI: 10.1007/s001220051615.

Junior, F.C., de Oliveira, A.G., de Oliveira, L.A., dos Santos, G.R., Chagas, L.F.B., da Silva, A.L.L. \& da Luz Costa, J. (2015). Production of indole3-acetic acid by Bacillus isolated from different soils. Bulgarian Journal of Agricultural Science, 21(2), 282-287.

Katz, E. \& Demain, A.L. (1997). The peptide antibiotics of Bacillus, chemistry, biogenesis, and possible functions. Bacteriol Rev., 41, 449474.

Kementerian Pertanian. (2016). Outlook Kkomoditas Pertanian Sub Sektor Tanaman Pangan: Jagung. Pusat Data dan Sistem Informasi Pertanian, Kementerian Pertanian, Jakarta. (On-line), http://epublikasi.setjen.pertanian.go.id/arsipoutlook/81-outlook-tanaman-pangan/432outlook-jagung-2016. Diakses 18 Juli 2018.

Keswani, C., Singh, H.B., Hermosa, R., GarcíaEstrada, C., Caradus, J., He, Y.-W., MezaacheAichour, S., Glare, T.R., Borriss, R., Vinale, F. \& Sansinenea, E. (2019). Antimicrobial secondary metabolites from agriculturally important fungi as next biocontrol agents. Applied Micro -biology and Biotechnology 103: 9287-9303. DOI: https://10.1007/s00253-019-10209-2.

Király, L., Barna, B. \& Király, Z. (2007). Plant resistance to pathogen infection: forms and mechanisms of innate and acquired resistance. Journal of Phytopathology, 155(7-8),385-396. DOI: https://10.1111/j.1439-0434.2007.01264.x.

Kuta, F.A., Nimzing, L., \& Orka'a, P. (2009). Screening of Bacillus species with potentials of antibiotics production. Applied Medical Informatics, 24(12), 42-46.

Lahre, S.K., Khare, N., Lakpale, N. \& Chaliganjewar, S.D. (2012). Efficacy of bio-agents and organic amendments against Sclerotium rolfsii in chickpea. Journal of Plant Disease Sciences 7 (1), 32-34.
Lee, S.W., Lee, S.H., Lan, J.M., Park, K.H., Jang, I.B. \& Kim, K.H. (2016). Control of soil-borne pathogens in ginseng cultivation through the use of cultured green manure crop and solarization in greenhouse facilities. Korean Journal of Medicinal Crop Science, 24(2), 136-142. DOI: https://10.7783/kjmcs.2016.24.2.136.

Lu, Z., Guo, W. \& Liu, C. (2018). Isolation, identification and characterization of novel Bacillus subtilis. J Vet Med Sci., 80(3), 427433. DOI: https://10.1292/jvms.16-0572.

Mulyati, S. 2009. Pengendalian penyakit hawar pelepah daun (Rhizoctonia solani) menggunakan beberapa agensia hayati golongan cendawan pada tanaman jagung (Zea mays). J. Agronomi, 13 (2), 37-43.

Noble, R. (2011). Risks and benefits of soil amendment with composts in relation to plant pathogens. Australasian Plant Pathology, 40(2), 157167. DOI:https://10.1007/s13313-010-0025-7.

Noordzij, M., Dekker, F.W., Zoccali, C. \& Jager, K.J. (2010). Measures of disease frequency: prevalence and incidence. Nephron Clinical Practice,115, c17-c20. DOI: https://10.1159/ 000286345.

Nuryani, W., Yusuf, E.S., Djatnika, I., Hanudin \& Marwoto, B. (2011). Pengendalian penyakit layu fusarium pada subang gladiol dengan pengasapan dan biopestisida. J. Hortikultura, 21(1), 40-50.

Oktari, A., Supriatin, Y., Kamal, M., \& Syafrullah, H. (2017). The bacterial endospore stain on schaeffer fulton using variation of methylene blue solution. IOP Conf. Series: Journal of Physics: Conf. Series, 812(2017): 012066. DOI: https://10.1088/1742-6596/812/1/012066.

Orozco-Avitia, A., Esqueda, M., Meza, A., Tiznado, M., Gutierrez, A. \& Gardea, A. (2013). Temperature effect on Rhizoctonia solani analyzed by microcalorimetry. American Journal of Agricultural and Biological Sciences, 8(2), 162-166. DOI: 10.3844/ajabssp.2013.162.166.

Pappas, M.L., Liapoura, M., Papantoniou, D., Avramidou, M., Kavroulakis, N., Weinhold, A., Broufas, G.D. \& Papadopoulou, K.K. 2018. The beneficial endophytic fungus Fusarium solani strain $\mathrm{K}$ alters tomato responses against spider mites to the benefit of the plant. Front. Plant Sci., 06 November 2018. DOI: https:// doi.org/10.3389/fpls.2018.01603.

Rozy, F., Liestiany, E., \& Maftuhah. (2004). Kemampuan mikoriza mengendalikan serangan Rhizoctonia solani Kuhn pada kedelai. Jurnal Agroscientiae, 2(11), 91-98.

Shafi, J., Tian, H. \& Ji, M. (2017). Bacillus species as versatile weapons for plant pathogens: A review. Biotechnology \& Biotechnological Equipment 
$31(3), \quad 446-459 . \quad$ DOI:10.1080/13102818. 2017. 1286950.

Sharma, L., Goswami, S. \& Nagrale, D.T. (2013). Culture and physiological variability in Rhizoctonia solani, responsible for foliarand lesions on aerial part of soybean. Journal of Applied and Natural Science, 5(1), 41-46.

Simarmata, R., Lekatompeassy, S., \& Sukiman, H. (2007). Isolasi mikroba endofitik dari tanaman obat sambung nyawa (Gynura procumbens) dan analisis potensinya sebagai antimikroba. Berk. Penel. Hayati, 13, 85-90.

Soenartiningsih, Ambarwati, T..J., Pusposenjoyo, N. \& Baon, J.B. (2006). Pengaruh inokulasi jamur mikoriza arbuskular terhadap penyakit busuk pelepah pada jagung di lapangan. Majalah Ilmiah Biologi Biosfera, 23(2), 86-91. DOI: https://10.20884/1.mib.2006.23.2.161.

Sousa, A.M., Machado, I., Nicolau, A. \& Pereira, M.O. (2013). Improvements on colony morphology identification towards bacterial profiling. Journal of Microbiological Methods, 95, 327-335. DOI: https://10.1016/j.mimet. 2013. 09. 020.

Sorokulova, I. 2013. Modern status and perspectives of Bacillus bacteria as probiotics. Journal of Probiotics \& Health, 1(4), e106. DOI: https:// 10. 4172/2329-8901.1000e10.

Suryawanshi, P.P., Krishnaraj, P.U. \& Prashanthi, S.K. (2019). Morphological and molecular characterization of Rhizoctonia solani causing sheath blight in rice. International Journal of Current Microbiology and Applied Sciences, 8(01), 1714-1721. DOI: https://10.20546/ijcmas. 2019. 801.182.

Taherdoost, H. (2016). Sampling methods in research methodology; How to choose a sampling technique for research. International Journal of Academic Research in Management (IJARM), 5(2), 1827.

Wagi, S. \& Ahmed, A. (2019). Bacillus spp.: potent microfactories of bacterial IAA. Peer J. 7, e7258. DOI: $h t t p s: / / 10.7717 /$ peerj. 7258.

Watanabe, T. (2002). Pictorial Atlas of Soil and Seed Fungi Morphologies of Cultured Fungi and Key to Species 2nd Edition. CRC Press. Boca Raton, USA. 504 pp.

Whittenbury, R. (1964). Hydrogen peroxide formation and catalase activity in the lactic acid bacteria. Microbiology, 35(1), 13-26. DOI:https://10.1099/ 00221287-35-1-13.

Yusra, F. Azima, Novelina, \& Periadnadi. (2014). Isolasi dan identifikasi mikroflora indigenous dalam budu. Agritech, 34(3), 316-321.

Zhao, L., Xu, Y., Lai, X.-H., Shan, C., Deng, Z., \& Ji, Y. 2015. Screening and characterization of endophytic Bacillus and Paenibacillus strains from medicinal plant Lonicera japonica for use as potential plant growth promoters. Braz J Microbiol. 46(4), 977-989. DOI: https://10.1590/ S1517-838246420140024. 